\title{
Conflicts as constraints to effective management of tertiary institutions in Nigeria: the way forward
}

\author{
Adoga James Ada \\ Department of Educational Foundations and Management, College of Education, Oju,
} Benue State, Nigeria

E-mail address: adabrown2013@gmail.com

\begin{abstract}
This study examines the concepts of conflict and constrai institutions in Nigeria. It makes a clarification of causes, and typ and fict management in higher institutions of learning. The paper observes that manageme toachers, government. Trade Unions may be sources of conflict for one reason or te other. Neverthel os, the outcomes of such conflicts causes prolong of academic activities, destruc of life and properties and in some cases render school environment completely insecure for seriou ademic acti ities not beneficial to students, institutions and the society at large. It recommends that th forw $\mathrm{d}$ should be proper handling of higher institutions by management and govern to be im amocratic in handling conflicts by creating avenues for discussing and designing. T Phoncludes that conflict is an attendant feature of human interaction in every organization which nn $u$ bo minated, therefore, maintaining a cordial relationship between staff, students by onol auth ity, is necessary, also involving students and trade unions in decision making proces app red to the most effective way forward for effective management of tertiary institutic

Keywords: higher instituti s; manage and government; school authority; conflict

1. INTROD' CTIO

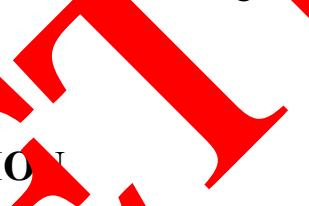

The-conten rary y orld is increasingly multicultural and the identify conflicts resulting from anis netimo eatens sustainable human development. This makes the promotion of up. tand ho and dialogue to be a prime issue in the management of multiculturalism, global peace scum (Oloyede, 1999). Conflict is an inevitable friction in any organization. Efficien deffective management of conflicts is fundamental to the development of any society pary cularly tertiary institution of learning. Conflict in tertiary institution is inescapable. Conflict exits at every level of our academic world. And while conflict can be negative and can cause deep rifts in the frame work of the institution, it can also be used as a tool to take the institution and the people in it from stagnation to a new level of effectiveness. What makes the difference is conflict management (Hotton, 1998). Organizational behaviour is positively related to organizational output. For this reason, the educational administrator needs to take conflict management issues as a very important issues because conflicts and attempts towards resolution are perhaps the most powerful force existing for bringing about changes in pattern of organizational behaviour (Hanson, 1991). Indeed one of the commonly expressed concerns
\end{abstract}


of organizational people in developing countries is that permanence of internal conflicts in their organization. Conflicts will always occur but a well managed conflict will not degenerate to violence. Since violence will not erupt without conflict as a antecedents, one can assume that many of the conflicts in tertiary institutions and insecurity degenerated is because their antecedents/cause were not properly managed or that the conflicting parties did not explore the power of communication and conflict manger's personality in resolving the crises (Agbona, Yusuf \& Onifade, 2009). The important of tertiary education to the national development cannot be overemphasized. However, no meaningful development can take place in a crisisridden system torn apart by crisis as witnessed in educational institution in Nigerio-oday. Today, students, staff (Academics \& non-academics) poses conflict as militancy ir the nar 's tertiary institutions inform of violence revolts, protests, unrests as well as ince nt closure schools for months in the wake of unrest. This have become regular charact ristio fNigeri tertiary institutions (Adeyemi, Ekurdayo \& Alonge, 2010) The educat nal adml ato is faced with myriads of problems arising from conflict and so, one $s^{\prime}$ uld b ble to cvice necessary conflict management mechanisms if the objectives of the che to be chieved.

\section{CONCEPTUAL FRAME WORK}

Tertiary institutions are always in crises when onflicts occur, w/, ch vary from campus to campus depending on the size, location, stu nt populati $n$, mission, specialization, governance and unionization. What can trigger conf perhaps ven large scale ones, on one campus may be inconceivable on another. Aouba, (20 to conflict as a struggle or contest, when workers and management have natible, conflicting or irreconcilable views, on issues, that could lead to conflict. He main ine an in thinkable to find any industrial society without industrial conflict, strossing tha even Japan which is regarded as the Mecca of industrial harmony has elements of $\mathrm{in}$ strial co flict in one form or the other.

Ezegbe in Ndil (1997) res onflict as mutual hostility in inter human relations in educational institutions in 5 rì uturam stility can occur in form of results, black Mailing, withdraws of love and sport, wit wal of resources, salaries, wages, fringe benefits, or incentive, sudden tra sfer spension, nolent demonstration and so on. Conflict can occur at the level of int ousonal, ter group/organization or intra-organizational relationship involving chief Executive (Vio nancellors, provost or rector) and the rest of the staff, the students the per-o yate cadre, and the subordinates, the senior and the junior staff, the student and $\mathrm{Sc}$ ' authori, the community and the school. Many people view conflict as an activity is ah to ally negative and has no redeeming qualities. While other school of thoy tht ac pted it a dysfunctional, destructive and the same times as a catalyst for change, crea ity 1moduction (Posisha \& Ogbuvwa, 2009). Conflict results from human interaction in the text of mcompatible ends and where one's inability to satisfy needs or ends depends on choice cisions and behaviour of others. It is therefore possible to argue that conflict is endemic in nature of human relationships and societies, It is the result of interaction among people, and unavoidable concomitant of choices and decisions and an expression of the basic fact of human interdependence (Adejuwon \& Okewale, 2009)

Alabi, (2010) sees conflict to be in opposition to another or each other, or disagreement" Kesterner and Ray (2002) see conflict as a two parties (individuals, group, State) are involved and strived for goals which can only be reached by one party, and or want to employ incompatible means to achieve a certain goal. It thus implies struggle over values or claims to 
status, power and scarce resources in which the aims of the groups or individual involved are not only to obtain the desired values but neutralize, injure or eliminate rivals.

When differences come to force, collisions, strives, controversies, discords, friction and disagreements cannot be avoided. These are evidences of conflicts. This phenomenon informed the submission of Akomolafe (2002), that conflict is unavoidable in any organization. Ajayi and Ayodele (2002) believe that conflict is inevitable, while Gilhin (2004) submitted that conflict is a normal part of man's social relations. No human organization is thus immune to conflict.

\section{TYPES AND SOURCES OF CONFLICTS}

Institution of learning, both secular and non-secular, are perfectly gr alified to b gar,ed as organizations in all respects. Tertiary institutions have very promi nt rol to pla $n$ the nation's over all development. Many reasons could be adduced for he ase in t level of occurrence of conflicts in recent times when compared to some $y$ ars back. ku, E nerado and Okeke 2008) identified the following types of conflicts.

* Role Conflict: A person conforms to two or more co tudictor ts of roles at the same time. Conformity to one role would prevent the ex cution of anotho

* Personality Conflict: A person who holds a p nciple (e.g. democratic principle) finds himself operating another principle (e.g. autocrat rinciple)

* Role-Personality: A person's role expe tion is at ce with his need disposition. For example, a principal is expected to use so row inment to improve the lots of the school but if he sell them in order to enrich hi se s, hy will be experiencing role-personality conflict.

* Cognitive conflict: This $o$ tre ol differen / in perspectives or judgments about issues. Legitimate differences op oxpessed, better ideas can be developed and problems can be soly d when th vpe of conflict occurs. Its constructive in nature.

* Affective Confli : Th has to do vith person's emotion and it is directed against people. It can lead to nger, bh ness, goal displacement and lower quantity decision. It is destructive natre.

* Organize nct: T is is a group activity. it has for example the blessing of the entire groun to sue confli $\Lambda$, if a union support a conflict, it is an organized conflict.

* norg ized Cy Aict: This is the type of conflict in which individuals responds to conflict

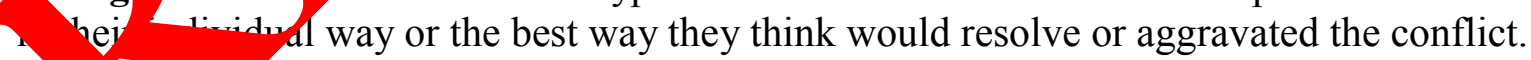
Th. pe of conflict may not have the blessing of the entire group or union.

(Iyay Sshio and Okojie, 2011) agreed with the above that conflicts can broadly be two types at work organized and Unorganized, and maintained that conflicts occur with employer, public or private which may take the form of:

* Peaceful bargaining and grievance handling

* By boycotts

* By political action

* By restriction of output, of sabotage

* insubordination and physical attack

* By absenteeism 
* By personal turn over, ban on overtime

- Strikes

According to them, industrial situation in which workers experience sufficiently acute deprivation, unrest will be expressed in some form. Sources of conflict according to Iyayi, Oshio, \& Okojie, (2011) are numerous some are peculiar to respective tertiary institution and others located outside the school. That is to say sources of industrial conflict are internal, and external both often influencing one another.

The External Sources of Conflict Include:

* Government's industrial, economic and educational policies,

* Nature of labour legislation

* Unpatriotic and unethical behaviour of political class

* National economic mismanagement, and

* General distribution of wealth and power in society.

For a comprehensive Perception of conflict, Nye framework of the dynamic of conflict promoting factors as $\mathrm{s}^{1} \mathrm{~W}$ low:

\section{Individual Characteristics}

* Defensiveness

* Authoritarianism

* Prejudice

* Blind conforming and obeying tendo ies

* Aggressiveness

* Frustration

* Stress from over loading

* High level of needs

* Non satisfaction of hrm

* Selfishness/greedi ess

* Poor distorte com nication

* Unhealth varry

* Hared//acisr /Discrimin uon

* Poq tivator

* Un-cono ve wor ing/learning environment etc

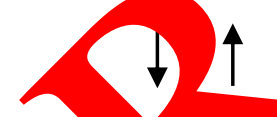

Interac Pattern

* Co petition

* Domination

* Provocation

\section{Internal sources of conflict would include:}

* Style of management.

* Nature of physical environment of the work place

* Orientation of staff

* Other conditions of service 
* Fairness and efficiency or otherwise of the promotion system, and
* Effectiveness and fairness of grievance and disputes procedure.

\section{CONCEPTUAL FRAME WORK OF DYNAMICS OF CONFLICT FACTORS}

Conflict promoting factors affect each other, Individual characteristics are capable of instigating and intensifying interaction pattern, and vice versa (the arrows between these two sets of factors). Conflict is produced from the combination of individual characterictinc and interaction patterns. once begins tends to intensify, and add to the very factors the proat it. (Nyc, 1973).

\section{CONFLICT ANALYSIS}

One common characteristic of formal of organization is th member eal y th conflict every day. Sometimes it is between a few individuals. S n nes it is ween groups. Sometimes these conflicts are contained with the operationa ysten f the organization. With a view to understanding and effectively handling conf $~-1$. educatio istitutions there are two distinct approaches to studying specific situations These are structu al and process models. Thomas in Dunette (1976) stated that process model ocuses upor the sequence of events with the needs to understand and intervene directly into th ream of e rents of an ongoing episode" The administrator traces dynamics of the events by in the impacts of each event on succeeding ones.

The structural model studies conditions, vhi conflict behaviour in a relationship, the parameters that initiate and directhehaviou n conflict situation are fired or at least slow to change. Such parameter include orm organiz tional roles and informal group membership. This approach is particularly ful i restruct,ring situation to facilitate desired behaviour patterns. Many organizati a cers an natural consequences of the system. Take for instance the Union and nagemen ationship and the controversy between school coaches who want games per od he time ta se and subject teachers who say it should be evening activity. The trig rof of th conflicts are built into system. The structural model here advocates the stady and reshap, of the conditions that trigger conflict.

\section{MA GEML TOFCONFLICTS AND THE WAY FORWARD}

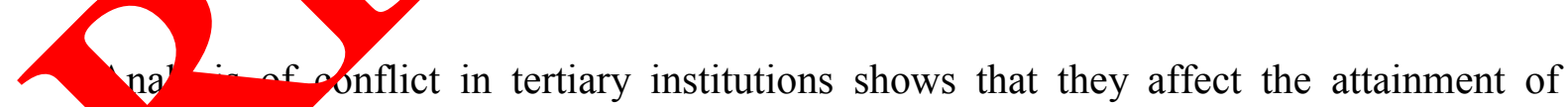
institu. gl goar positively or adversely. Conflict in some cases could facilitate co-operation, foster goa staff, students, institutional and authority and community, if not well managed, could lead to irreparable loss of lives, destruction of properties and disruption of normal academic activities. The survival of any institution therefore, largely depends upon the development of better means of resolving conflicts (Aja, 2012).

Management is process by which human and non-human resources are co-ordinated to accomplish a given set of objectives. (Nwachukwu, 1998). Conflict management according to Albert (2010) refers to the coordinated and timely application of political, economic, military and or security measures taken in response to a situation threatening peace, with the aim of 
defusing the tensed situation, Preventing escalation or achieving a peaceful settlement of a dispute. Aja in Handy (1978) indicates that the major way forward in management of conflicts include dialogue, Arbitration, Boxing the problem, confrontation and neglect/silence.

1. By Dialogue: The people in conflict are brought together to expose and discuss the issues and problems involved in the conflict aimed at gaining a clearer view of factors causing and promoting the conflict. It gives those in conflict the opportunity to express their feelings, their grievances and views on the matter. A healthy dialogue frees the mind of grudges and bitterness to bury the hatchet and settle the conflict.

2. Arbitration: Is a process by which a peace maker, arbitrator or peace pan setur conflict through appealing to the conscience of those in conflict.

3. By Confrontation: The issue and problem can be subjected deba betw those conflict or neutral groups in order to expose the problem and co, vince the co at ints of its emptiness.

4. In Boxing the Problem: The group or organization ide atios fa sesp onsible for the conflict. The problem is examined carefully throug ritical exu on of its aims and destroying the problem or exposing the triviali or much ad 0 -about nothing inherent in the identified problem(s)

5. Neglect or Silence: Can be used occasional b the chief Executives to prove to those in conflict that the conflict is not important to nerit the at ention of the administrator. Neglect or silence involves delaying tact which can disarm the combatant emotionally as they wait for days or anths on a cout any practical action on the part of the chief Executive. The bott unotion/anger can dwindle as the delay, neglect or silence continues to end the onfich ation should be taken in the use of this particular strategy, because $\cdot 1$ nce or eglect may also gather momentum one day to erupt like volcano which nay more d tyuction than good.

In resolving tertiar nstit n commct, developing a constructive communication process and influential flict nego or's personality are very important. No doubt, schools cannot avoid experie cins conflic or the other but a great deal of such conflict can be managed and be god from rupting school efforts towards attaining it manifest and latent goals if the conticting parties systematic in the way they communicate their grievances, situation of conf cuan readiness to negotiate for peace and if the negotiator mediating the resolution proc s of gor a personality (Agbonna, Yusuf \& Onifade, 2009).

ict ma ent in school demand appropriate leadership style of the school ady nistra $r$ or chr executive .Demers in Magaula (2007) articulated three strategies of peac olution between and among warring parties, mediation, arbitration and reconc, ion. Other strategies that can contribute to conflict management include effective catharsis, cr-ordinate goals, empathy, grit theory, culture of civility, synergy, an address by an influential person, satisfaction of maslow's hierarchy of human needs, prayers and separation devices.

\section{CONCLUSION}

There is no doubt that just as conflicts abound in human beings so it is in tertiary institutions. The school administrator therefore needs managerial expertise and leadership qualities to bring the staff, students and communities together to fight a common course to 
create conflict free situation for academic success. Ola and Oyibo (2000). Observed that the current orientation is that conflict is an inherent aspect of every organization that dysfunctional conflict should be resolved, while functional conflict should be accepted and infact encouraged.

Nigerian leaders as well as management of tertiary institutions in the country also need to create avenues for discussing and designing popularly accepted non-violent strategy for managing conflicts.

\section{RECOMMENDATIONS}

It is recommended that school authorities in tertiary institutions $\mathrm{s}^{1}$ ld be mo democratic in handling students' affairs, involve students in decision making roc especia on issues that boarders on them. Students should be called for dialogue rom time time to curb conflicts. Authorities of tertiary institution should always em rk or cus in e on preventive strategies in order to reduce crisis rather than cy tiv casures Conflict management in tertiary institution requires giving consideration o problen ving lechniques along with proper use of authority, observance of rules and co tions, prop structuring of institution, provision of adequate communication netyos s an ncouraging meaningful participation of stakeholders in resolving conflicts. T s ategy or state in maning conflict need to be redesigned. For instance, the use of military operatives to trouble shoot crisis in tertiary institutions were not the best way of ma ging confli t as they had increased the number of casualties. In the work of Mohamedbhat cited in Magagula (2007) courses on conflict management and resolution, peace aducation, c cation, good governance, basic and human rights, separation of powers of rule of law etc and teaching of peace as a General Nigerian Studi $(G N$ th a view to making Nigerian tertiary
institutions conflict free is recommended.

\section{References}

[1] Adejuwon K. D, $0 \mathrm{~kg}$ e R. A $(2,09)$. Ethnic militancy, insurrections and democracy in Africa; The as of $\mathrm{N}$ ia, journal of social and policy issues; Vol. 6, No 4.

[2] Adeyemi 2. O, E undayo H 1., Ahonge H. O. (2010). Managing students crises in tertiary ituti ns in Vigeria. Journal of Research in National Development Vol. 1 June

[3] Agb S. A. 'usuf A., Onifade A. B. (2009). Communication and conflict manager's erso, lity in su ol security and conflict management. Being a text of paper presented the th $A$ nnval National Conference of social students Association of Nigeria. Held at M. Tel Uteuola college of primary education Noforija, Epe, Lagos State, from $17^{\text {th }}$ to $20^{\text {th }}-2009$

[4] AgubaC. R. (2009). Educational administration and management: issues and perspectives. Enugu: Tons and Tons PDS.

[5] Aja O. J. (2012). Conflicts as a barrier in tertiary institutions for national transformation. A paper presented at the $31^{\text {st }}$ Annual national conference of Nigerian association for education administration and planning (NAEAP) October, in Benue Hotels Makurdi.

[6] Alabi A. O (2010). Management of conflicts and crises in Nigeria: educational planner's view. Research journal of social sciences vol. 2 No 6. 
[7] Albert I. O (2011). Building peace, advancing democracy, experience with the third party interventions in Nigeria's conflicts. Ibadan: John Archers publications Ltd.

[8] Ayodele J. B., Adewumi J. O (2007). The incidence and management of conflicts in secular and non-secular tertiary institutions in south west Nigeria. Educational research and review, Vol. 2 (5).

[9] Dunnette M. (1976). Hand book of industrial and organizational psychology. Chicago; Randy McWally.

[10] Gillin C. T. (2004). Conflict resolution, negotiation and team building. Arts an contemporary studies Ryerson University.

[11] Hanson M. (1991). Education administration and organization behaviour. Massachusetts: Ally and Bacon.

[12] Iyayi F., Oshio E., Okojie J. (2011). Critical issues in Universit vern ${ }^{2}$, seria. Lagos: Malthouse press limited.

[13] Kestener B. P., Ray L. (2002). The conflict resolution t manual. Jossey-Bass, U.S.A.

[14] Magagula C. M. (2007). Conflict resolution and $y$ ana ement: th te of Africa higher education institutions. Paper presented at a sem har celebrating the African University day at University of Swaziland, Kwaluseni. 15 November.

[15] Ndu A., Ocho L. O., Okeke B. S. (1977). Dynam of edu ational administration and management: the Nigeria perspective. wa: Mekn puolishers Ltd. [16] Ola R. F., Oyibo E. E. (2000). Administ, tive on and their applications, Ibadan:
Amifitop Books.

[17] Oloyede I. O (1999). Cult al pl alism as challenge to effectiveness of University

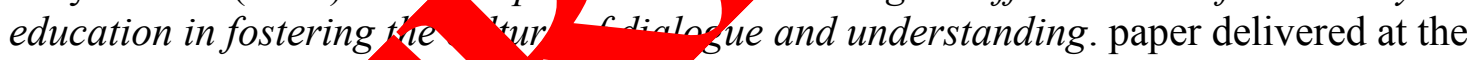
2009 IAU confereng Or the of higner education in fostering the culture of dialogue and understandin Nigeria. L on: Notre Dame University.

[18] Posigha B. E Q (2009). Conflict among library staff in Bayelsa and Delta States of N geria. Interna 1 journal of labour and organizational psychology. Vol.3,

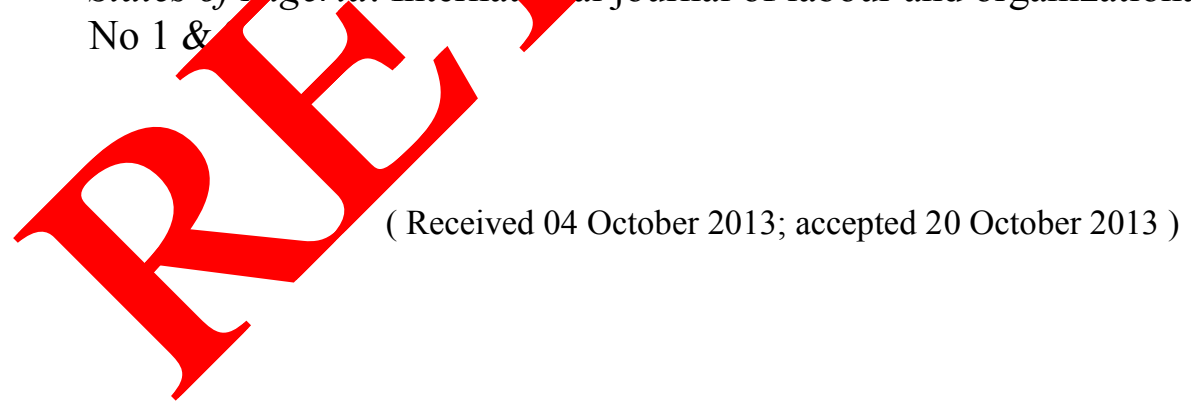

